\title{
Hindistan ve Pakistan İlişkileri: Bölgesel Rekabetin Nükleer Silahlanma Stratejilerine Etkileri
}

DOI: $10.26466 /$ opus. 857115

\begin{abstract}
Engin Koc*
* Dr. Öğr. Üyesi, Bursa Teknik Üniversitesi, İnsan ve Toplum Bilimleri Fakültesi, Bursa/Türkiye E-Posta: engin.koc@btu.edu.tr

ORCID: $\underline{0000-0003-3682-8718}$
\end{abstract}

Öz

Bu makalede Hindistan ve Pakistan'ın nükleer faaliyetleri ve politikaları değerlendirilecektir. Hindistan ve Pakistan nükleer teknoloji geliştirme konusunda ve bu teknoloji yardımı ile silah elde etmede birbirlerinden farklı nedenlere sahiptir. Hindistan, 1964 yılında Çin'in nükleer patlama gerçekleştirmesinden sonra nükleer silah sahibi olmak için çalışmalarını başlattı. Pakistan ise, Hindistan'ın 1974 yılında nükleer silah elde etmesi sonrası kendi güvenliğini korumak ve nükleer denge oluşturmak için nükleer silah çalışmalarını başlattı. Taraflar, bölgesel gü̈ç dengesinde varlı̆̆ını ve istikrarını koruması için Çin, Rusya ve ABD gibi bölge dışı ülkeler ile askeri ve ekonomik ilişkilerini geliştirdi. Bu da HindistanPakistan uyuşmazlığın ve Keşmir sorununun uluslararası bir probleme dönüşmesine sebep oldu. Bu sorunlar üzerinden bölgesel tansiyonun giderek yükselmesi ve meselenin nükleer bir çatışmaya dönüşmesi ihtimalinin olması her iki taraf açısından katlanılamaz büyük ekonomik ve askeri maliyetleri ortaya çıkardı. Bu çalışmada, Hindistan ve Pakistan'ın neden nükleer silah elde etmek istediklerini. Nasıl nükleer silah elde ettiklerini. Nükleer silah elde ettikten sonra iç politikada, bölgesel politikada ve küresel politikada ne gibi sonuçlar ortaya çıkardiğı analiz edilmiştir.

Anahtar Kelimeler: Nükleer Silahlar, Hindistan, Pakistan, Nükleer Doktrin, Keşmir. 


\title{
India and Pakistan Relations: The Effects of Regional Competition on Nuclear Armament Strategies
}

\begin{abstract}
In this article, will examine the nuclear actions and policies of India and Pakistan. India and Pakistan have different reasons in order to developing nuclear power technology and obtaining nuclear weapons with the help of this technology. India started its works to acquire nuclear weapons after China's first nuclear explosion in 1964. Pakistan, on the other hand, started nuclear weapons works in order to protect its own security and create a nuclear balance after India's first nuclear explosion in 1974. The parties developed military and economic relations with non-regional countries such as China, Russia and the USA in order to maintain its presence and stability in the regional balance of power. This caused the India-Pakistan conflict and the Kashmir issue to turn into an international problem. Increasing regional tensions over these problems and the possibility of the issue turning into a nuclear conflict resulted in unbearable economic and military costs for both sides. In this study, we examine why do India and Pakistan wish to obtain nuclear weapons? How did they get nuclear weapons? In this paper, analysed the effects of the nuclear power obtaintment of India and Pakistan based on domestic, regional and international politics.
\end{abstract}

Keywords: Nuclear Weapons, India, Pakistan, Nuclear Doctrine, Kashmir 


\section{Giriş}

İnsanlar, kendi güvenliğini korumak ve varlığını devam ettirmek için tarih boyunca silahlanmış ve bu silahlarla rakiplerine karşı savaşmışlardır. İnsanlar, ilk çağlarda basit taş, sopa ve demirden yapılan savaş aletleri kullanmıştır. Daha sonra savaş meydanlarında kullanılmak için mancınık ve barutun icat edilmesi ile kısmi olarak kitlesel zararlara neden olabilecek savaş araç-gereçleri icat edilmiştir (Özey, 2007, s.38-40). Modern savaş teknolojisinin gelişmesi ve savaş alanlarında kullanılması ile birlikte geçmişte yaşanmış meydan savaşlarından çok daha fazla insan ve mal kaybı ortaya çıkmıştır (Yılmaz, 2013, s.1). Teknoloji ve diğer alanlarda gelişen insanlık aynı zamanda edindiği yeni tecrübeleri savaşlara da yansıtmıştır. Dolayısıyla, insanlığın gelişiminde kazanmış olduğu her bir ivme savaş alanlarına da doğrudan yansımaları olmuştur (Bektaş ve Gündoğdu, 2019, s.50).

Deniz altı, tanklar, savaş gemileri, uçaklar ve birtakım kimyasal silahların kullanıldığı I. Dünya Savaşı sonunda dokuz milyon insan hayatını kaybetmiştir. Savunma alanında meydana gelen gelişmeler ve icat edilen yeni savaş teknikleri ile ilerleyen yıllarda kullanılan konvansiyonel silahların tahrip kapasitesinin daha da geniş̧lemesi sağlanmıştır. 21.yüzyıl uluslararası siyasal sisteminde kitle imha silahları olarak bilinen kimyasal, biyolojik ve nükleer silahların sayı ve tahrip gücü giderek artmıştır. Kitle imha silahlarının askeri olmayan sivil ve terörist unsurların kolaylıkla sahip olma olasılığı kitle imha silahlarının caydırıcılığının yeniden tanımlanmasını gerektirmiştir (Arı, 2004, s. 58).

Silah teknolojisinde yaşanan baş döndürücü gelişmeler, nükleer silahlar, balistik füzeler ve bunları oldukça sofistike hale getiren gönderme araçlarında gelinen nokta, süper devletlerin de dahil olmak üzere vurulabilir olduğu ve saldırıya açı olduğunu göstermektedir. Ayrıca silah teknolojisinde yaşanan bu gelişme ulus devlet sınırlarının giderek anlamsızlaştığını göstermektedir (Arı, 2008, s. 73). Kitle imha silahları içerisinde ise nükleer silahlar tahrip, caydırıcılık ve yıkım anlamında diğerlerinden kat kat fazla etkiye sahip olmaktadır.

II. Dünya Savaşı sonrası kurulan iki kutuplu uluslararası sistemin güç denge oluşumunda nükleer silahlar belirleyici bir rol oynamışlardır. ABD'nin 1945-1953 yıllarındaki nükleer tekeli ve Sovyetlere üstünlüğü 
1949 yılında Sovyetler 'in ilk atom bombası testinin gerçekleşmesi ile kırılsa da 1952 yılında nükleer bombadan çok daha tesirli olan Hidrojen bombasının $\mathrm{ABD}$ tarafından patlatılması $\mathrm{ABD}^{\prime}$ ye stratejik üstünlük vermiştir. 1953 yılında bu silaha Sovyetlerin sahip olması ile birlikte iki kutup lideri arasında nükleer denge sağlanmıştır (Sönmezoğlu, Güneş ve Keleşoğlu, 2015, s.30). ABD ve Sovyetlerin arasında nükleer denge sağlanması karşılıklı savunma ve caydırıcılık oluşturmuştur. Taraflar arasında nükleer silahlanma alanında rekabetin kontrol edilememesi ve bunun olası bir çatışma durumunda bütün insanlık açısından kaçınılmaz sonuçlarının olacağının görülmesi Dehşet Dengesini (Balance of Terror) ortaya çıkarmıştır (Wohlstetter, 1958).

Herhangi bir nükleer tahribata karşı bir savunma mekanizması geliştirilemediğinden dolayı nükleer silahlara sahip olan devletler diğer devletlere karşı büyük bir stratejik avantaj sağlamaktadır. Bu nedenlerden dolayı nükleer güce sahip olan devletler bunu savunma, ulusal güvenlik ve dış politikalarının merkezine almıştır (İşbilen, 2009, s.55).

Waltz'a göre ise devletlerin nükleer silah sahibi olmasının bazı ontolojik nedenleri vardır. Bunlar;

1- Büyük güçler her zaman diğer rakip güçlerin silahlarını hesaba katar ve genellikle onların son teknolojideki silahlarının taklit veya bir benzerlerini yaparlar.

2- Bir devlet diğer büyük devletlerin kendisine saldırdığında müttefiklerinin karşı tarafa misilleme yapmayacağını düşündükleri için nükleer silah sahibi olmak isteyebilir. İngiltere ve Fransa, ABD'nin herhangi bir Sovyet nükleer saldırı karşısında nükleer koruma şemsiyesi tarafından korunamayacağı ihtimalinden dolayı nükleer silah sahibi olmak istemiştir.

3- Ülkeler hali hazırdaki veya gelecekteki düşmanları ile kendileri arasında çıkacak bir çatışmada konvansiyonel üstünlüğü sağlayacakları korkusu ile nükleer silah sahibi olmak istemişlerdir.

4- Bazı ülkeler, konvansiyonel silahlanma yarışı ve ekonomik iyileşmeyi nükleer silaha sahip olarak daha ucuz ve güvenli bir şekle sokacaklarını düşünmektedirler.

5- Devletler saldırgan (offensive) politikalarını uygulamak için nükleer silah elde etmeye çalışırlar. 
6- Ülkeler sahip oldukları uluslararası konumu güçlendirmek için nükleer silah sahibi olmak istemişlerdir (Waltz, 1981).

Nükleer silahlanmanın yarım yüzyıllık bir tarihi olmasına rağmen, nükleer güç sahibi olan ve olmak isteyenler devletlerin bir davranış kalıbına sahip oldukların bile söyleyebiliriz. Devletler uluslararası ilişkilerin anarşik yapısından dolayı birbirlerine karşı korku duymaktadırlar. Bu korku da devletlerin niceliksel dayanma ve tahrip gücünü arttıran kitle silahları elde etmeye yöneltmiştir. ABD bu silahları Japonya'ya karşı kullanmış ve Sovyetlere karşıda elinde caydırıcı bir güç olarak bulundurmak istemiştir. Sovyetler ise, nükleer silah elde etmiş ve Çin'in nükleer silah teknolojisinin kurulmasına destek vererek $\mathrm{ABD}^{\prime}$ ye karşı denge kurmaya çalışmıştır. Çin'e karşı denge kurmak için Hindistan, Hindistan'a yönelik denge kurmak için ise nihayetinde Pakistan desteklenmiştir (Polk, 2007, s.224).

Soğuk Savaşın ilk on yılında ABD ve SSCB uluslararası nükleer tekele hâkimdi. Fakat bu durum, İngiltere, Fransa ve Çin'in nükleer güç elde etmesi ile değişti. (Climbala, 2010). 1968 yılında imzalanan Nükleer Silahların Yayılmasını Önleme Anlaşmasına (NPT) devletlerin bakış açısı birbirlerinden farklı olmuştur. NPT'nin temel mantığında meşru nükleer silah gücüne sahip ülkeleri tanımış ve ondan başka ülkelerin nükleer silah sahibi olma durumunu meşru karşılamamıştır (Balbay, 2006, s.13). Soğuk Savaş blok önderleri olan ABD ve Sovyetler nükleer güç hiyerarşisindeki mevkilerini muhafaza etmek ve kendilerini uzun zamanda nükleer bir tehditten muhafaza etmek için antlaşmanın mimarı olmak ile birlikte bu anlaşmanın en güçlü destekleyicileriydi. NPT'ye göre 1 Ocak 1967 tarihine kadar nükleer bomba denemiş ve başarı elde etmiş olan devletler nükleer kulüpte yer alacaktır. İngiltere de ABD ve Sovyetler Birliğinden sonra NPT'yi imzalamıştır. Fransa ve Çin ise nükleer güç sahibi olmak ile birlikte hidrojen bombasına sahip değillerdi (Sönmezoğlu, Güneş ve Keleşoğlu, 2015, ss. 142-144). De facto nükleer güç olarak kabul edilen devletler ise; İsrail, Hindistan ve Pakistan dır. Hindistan ve Pakistan gibi devletler aynı zamanda kendisine düşman olan sınır komşularının nükleer silaha sahip olması ve kendi konvansiyonel gücünün bu tehdide mukabil gelemeyeceğini anlaması ve uluslararası sistem tarafından nükleer koruma garantisine sahip olmamaları devletleri kendi güvenlik 
ve sınırlarını korumak için nükleer silahlanmaya önem vermiştir (Sagan, 1997, ss. 67-69).

Hindistan ve Pakistan arasında tarihi, dini, etnik, kimliksel, teritoriyal ve benzeri gibi birçok ihtilaflı alanlar bulunmaktadır. İki ülkenin ilişkilerini analiz edeceğimiz bu çalışmada ortaya çıkan problem ve çatışmaların derin tarihi kökenlerinin yerine mevcut güvenlik kaygılarının nükleer silahlanmaya olan etkisi irdelenecektir. Bu çalışmada, Hindistan ve Pakistan'ın neden nükleer silah elde etmek istediklerini? Nasıl nükleer silah elde ettiklerini? Nükleer silah elde ettikten sonra iç politikada, bölgesel politikada ve küresel politikada sonuç olarak ne olduğu analiz edilmeye çalışılacaktır.

\section{Güney Asya'da Nükleer Silahlanmaya Giden Yol: Bölünme, Savaş ve Güvenlikleştirme}

1945 yılında İngiltere II. Dünya Savaşının yıkıcı etkisi nedeniyle oldukça harap bir haldeydi. Bununla birlikte, Churchill'in seçimleri kaybetmesi ve Londra'nın ABD'ye olan finansal borcu nedeniyle ekonomik anlamda zor günler geçirmekteydi. İngilizler, Güney Asya'daki etkilerini kaybetmek istemeyerek bu bölgedeki kendi çıkarlarının korunması için Müslümanlar ve Hindular arasındaki ihtilafları ve bölünmeleri teşvik etmişti. Esasında, Gandhi bu fikre katılmayıp, İngilizlerin bu politikalarını şiddetli bir şekilde eleştirse de Pakistan Başbakanı olacak olan Cinnah bu fikri desteklemiştir (Riedel, 2014, s.50).

Hindistan'ın bağımsızlığının kazanılmasıyla birlikte bu bölgede yaşayan halklar arasında bölünme ortaya çıkmıştır. Neticede 1947 Ağustos ayında Hindistan ve Pakistan adıyla iki yeni devlet kurulmuştur (Crompton, 2007, s.10). Bölünmenin gerçekleşmesiyle birlikte İngilizler, kendi atadıkları eyaletlerin yöneticilerine istedikleri devlete katılma konusunda serbestlik vermiştir. O günün koşullarında Hindu hükümdarlar, Müslümanların çoğunluk olduğu bölgelerde hüküm sürdükleri gibi, Müslüman hükümdarlar Sih ve Hindu gibi halkların çoğunluğunu oluşturduğu taşralarda İngilizler namına hüküm sürmekteydi.

Hindistan'ın bölünmesi sonrası taşradaki yöneticilerin ortaya çıkan yeni otoritelere bağlanması kolay olmamıştır. Bu anlamda zaman zaman bu bağlılık zorlama ile ortaya çıkmıştır. Pakistan sınırına bitişik 
Müslümanların yaşadıkları bölgeler Pakistan'a katılmıştır. Diğer taraftan çoğu Hindu yönetiminde yer alan bölgeler Hindistan'a bağlanmıştır.Bununla birlikte, halkının \% 80 gibi ezici çoğunluğu Müslüman olan Cemmu-Keşmir bölgesi Pakistan'la birleşmek istemesine rağmen bölgenin Hindliler tarafından control edilmesi nedeniyle bu talep gerçekleştirilmemiştir. (Arı, 2000, s.32).

1947 yılında Hindistan ve Pakistan'ın iki farklı bağımsız devlet olarak tarih sahnesine çıkması ve taraflar arasında din merkezli kaynaklanan problemlerin siyasal bir şekil alması; iki ülke arasında günümüze kadar devam eden birçok sorunun ortaya çıkmasına neden olmuştur. Halkın \% 80'i Müslüman olan Keşmir topraklarının Hindu yönetimine bırakılmasına karşı çıkan Müslüman köylülerin Hintli güvenlik güçlerine isyan etmesi ile günümüze kadar sürecek olan Keşmir sorunu başlamış oldu (Arı, 2000, s.71-72). Hindistan ve Pakistan bağımsızlıklarından itibaren bölgedeki dini heterojenliği makul bir biçimde yönetememekle birlikte, 1948 yılında Keşmir'i ele geçirmek taraflar için ilk sıcak savaşı da başlatmışlardır. Bununla birlikte, ilerleyen yıllarda Pakistan'ın Bağdat Paktına girmesi, Hindistan'ın ise Bağlantısızlar Bloğunun önde gelen savunucularından birisi olmakla birlikte iki ülke arasındaki yarış daha da kızışmıştır (Sönmezoğlu, Güneş ve Keleşoğlu, 2015, s. 210). Pakistan ayrıca SEATO üzerinden Hindistan'a karşı diğer bir yandan cephe alarak güç kazanmak istemişse de kısa bir süre içerisinde SEATO'nun kendisi açısından koruma sağlamayacağına inanarak birlikten ayrılma kararı almıştır (Temizel, 2019, s.297).

Keşmir Pakistan için iki nedenden dolayı önemlidir. Birincisi; halkın \% 80'inin Müslüman olması, diğeri ise, Keşmir'den geçen İndus nehri ve kolları Pakistan'ın hidroelektrik santrallerinin enerji ihtiyacını sağlamasıdır. Hindistan ise bu bölgeyi Pakistan'ın denetimine bırakarak avantajlı bir konum elde etmesini istememektedir (Arl, 2000, s.35). Bununla birlikte, Keşmir'in ne Hindistan'ın ne de Pakistan'ın bir parçası olmaması ve bağımsız bir devlet olması gerektiğini savunan Keşmirlilerde mevcuttur.

BM'in Hindistan ve Pakistan' daki Askeri Gözlemciler Grubu (UNMOGIP) iki ülke arasındaki ateşkes hattını izlemeye başladı. Taraflar kontrol ettikleri bölgelerden çıkmamakla birlikte buradaki konumlarını 
güçlendirdiler. Keşmir'in beşte ikisi Hindistan, beşte üçü Pakistan tarafından kontrol edilmekle birlikte Pakistan, Çin'e Keşmir'den toprak verdi. Bugün Keşmir'in \%43'ü Hindistan, \%37 si Pakistan ve \%20'si Çin tarafından kontrol edilmektedir (Riedel, 2014, s.57).

1947 yılında ulus devlet parametreleri çerçevesinde kurulan Pakistan, territoriyal açıdan Hindistan, Afganistan, İran ve Çin gibi büyük ve kökleri geçmişin uzun yıllarına uzanan devletler ile komşuydu. Hindistan ile (Hindular ve Müslümanlar arasında) bağımsızlık sürecinde başlayan iç savaş Pakistan'ın günümüze kadar sürecek olan dini çatışmaların habercisi olmuştur (Hook, 2014, s.333).

Ekim 1962' de Hindistan ve Çin Savaşı Himalaya dağları yüksekliklerin de bulunan ve iki ülkenin tartışmalı sınır alanı iddia edilen bir coğrafi bölgede Hindistan'ın sömürge döneminde çizilen sınırların tanınmasını, Çin'in ise binlerce yıllık imparatorluk sırının değerlendirmeye alınmasında ısrar ettiği tarihin farklı yorumla değerlendirilmesi sonucu ortaya çıkmıştır (Kissinger, 2005, s.21). Bununla birlikte, Hindistan'ın Çin karşısında yenilmesi Hindistan'ın savunma stratejileri ve askeri teknolojisinin yenilenmesi adına önemli değişiklikleri hayata geçirmesi açısından da oldukça önemli bir süreç olmuştur. Çin'in saldırısına uğrayan Hindistan, Soğuk Savaş konjonktüründe yardım için ABD ve Batılı ülkelere başvurması taraflar arasındaki buzların erimesini hızlandırmıştır. Bununla birlikte Pakistan ise, ABD'nin Hindistan'a yakınlaşmasından rahatsız olmaya başlamış ve Çin ile ilişkilerini daha ileri boyutlara taşıma kararı almıştır.

1963 yılında Hindu ve Müslümanlar arasında çeşitli bölgelerde yaşanan küçük boyutlu çatışmalar Ağustos 1965'te iki ülke arasında bir savaşa sebebiyet vermiştir. Savaşta Hindistan'ın galip gelmesi ile birlikte BMGK'nun ateşkes kararı alması taraflar arasında savaşı dururmuştur (Sönmezoğlu, Güneş ve Keleşoğlu, 2015, s.211). Bağımsızlığını kazanan yeni ülkelerin sınırları da eski sömürgeci devletler tarafından belirlendiğinden ülke vatandaşlarının devletlerine karşı doğal bir bağlılığ yoktur. Devlet ve vatandaşlar arasındaki bu bağlantının olmaması şiddetli bir şekilde Hindistan ve Pakistan'ın ortaya çıkmasına sebep olurken, Müslümanların yaşadığı bölge olarak adlandırılan Pakistan'ın 1971'den sonra Pakistan ve Bangladeş olarak ikiye bölünmesine sebep olmuştur (Hook, 2014, s.78). 
Bangladeş nüfusunun ezici çoğunluğu Müslümanlardan oluşmakla birlikte kendilerini siyasi, ekonomik ve hukuki meselelerde Pakistan'a ait hissetmemesi 1970 yılına geldiğinde iki taraf arasında bir iç çatışma ve bölünmeye neden olacaktır. Aralık 1970'de yapılan meclis seçimini o zaman Doğu Pakistan olarak adlandırılan Bangladeş'te bağımsızlığ savunan Halk Partisinin alması ardından yaşanan çatışmalar bir iç savaşa dönüşmüş ve Hindistan bu savaşta Doğu Pakistanlıları desteklemiştir. Savaş esnasında 300.000 fazla insanın Hindistan'a sığınması ve Delhi'nin Bangladeşlilere artan desteğine karşılık Pakistan 3 Aralık 1971 tarihinde Batı Hindistan'daki bir hava alanını bombalayarak taraflar arasında doğrudan bir çatışma başlamıştır. Sovyetlerin Hindistan'ı, Çin ve ABD'nin Pakistan'ı desteklediği savaşı Hindistan kazanmış ve Pakistan kaybetmiştir (Miş, 2016, s.430-431). Pakistan'ın son üç savaşta Hindistan karşısındaki yenilgisi Pakistan'ın nükleer çalışmalara yoğunlaşmasını zorunlu kılmıştı. Bununla birlikte, Hindistan'ın Pakistan'ın yanı sıra Çin ve ABD'nin de kendisine baskı uygulama neticesinde nükleer çalışmalarını hızlandırmış ve 1974 yılında ilk nükleer denemesini başarı ile gerçekleştirmiştir (Riedel, 2014, s.86)

\section{Hindistan'in Nükleer Silahlanma Stratejileri}

Çalışmanın bu kısmında Hindistan'ın nükleer silah elde etme nedenleri analiz edilecektir. Bununla birlikte, Delhi yönetiminin nükleer silahları elde etmede ne gibi araçlara başvurduğu ve ne gibi engellerle karşılaştığ tartışılacaktır. Ayrıca, Hindistan'ın nükleer silah elde etmesinin bölgesel ve uluslararası politikaya olan etkileri bu bölümde incelenecektir.

\section{Hindistan'ın Nükleer Silah Elde Etme Nedenleri}

Hindistan kuruluşundan 1964 yılında devlet başkanı Nehru'nun ölümüne kadar nükleer silahlanmaya karşıt politik söylemlere sahip olmuştur. Nükleer güç elde etmenin sadece ekonomik ve bilimsel ihtiyaçlardan kaynaklı olması gerektiği savunulmuştur. Hindistan'ın böyle bir politikaya sahip olmasında yeni kurulmuş bir devlet olması, iç politikada sömürge sonrası istikrarı yakalayamaması etkili olduğu gibi, Soğuk Savaş 
konjonktüründe Bağlantısız Hareketi içerisinde yer alması da önemli bir nedendir.

Soğuk Savaş döneminde Güney Asya'da Hindistan-Pakistan arasında ortaya çıkan karmaşık ilişkiler küresel güçlerin bölgedeki etkinliğinden hariç bir şekilde anlaşılması mümkün değildir. 1960'larda SSCB-Çin ilişkilerinin bozularak birbirlerinde hızlı bir şekilde uzaklaşmaları da Pakistan-Hindistan ilişkilerini şekillendirmiştir. Pakistanlı devlet adamları ülkesel bütünlüğün Hindistan gibi güçlü bir devlet karşısında korunması ancak büyük güçlerin biri ile müttefiklik tesis edilerek sağlanacağını kavramıştır. Hindistan'ın Bağlantısızlar Bloğunda yer almakla birlikte Sovyetlere yakın politikalar izlemesi Pakistan'ı Batı merkezli ittifaklara (Bağdat Paktı) itmiştir. ABD ile stratejik askeri ilişkiler geliştirerek güçlenen Pakistan'a karşılık olarak Hindistan'da SSCB ile Dostluk Antlaşması imzalamıştır. Son olarak, 1960'ların sonlarına doğru ABD-Çin ilişkilerinin düzelmesi ile Sovyetler müttefiki olan Hindistan; $A B D$, Çin ve Pakistan tarafından stratejik olarak kuşatılmıştır (İşyar, 2009, s.201-202).

1962 yılında Çin' in Hindistan'ın toprak parçasının bir kısmını kısa süre içerisinde işgal etmesi Hindistan ordusunun modernleşmesine dolaylı bir şekilde teşvik edici bir etki olmuştur. Bu tarihten sonra Hindistan, ülkesel güvenliği sağlamak için hem savunma hem de saldırı stratejileri geliştirmeye başlamıştır. Hindistan'ın savunma stratejilerini geliştirme çabaları ülkenin ekonomik büyümesini de etkilemiştir. Bu süreç sonrası, AR-GE çalışmalarına verilen destek arttırılmış ve elektronik sanayisinde önem verilerek büyük teknolojik gelişmeler ortaya çıkmıştır. Fakat bu durum Hindistan'ın tedarikçi ülke olarak aynı zamanda dışarıya bağımlılığını arttırmıştır (Cohen, 2001, s.133).

Hindistan, 1964 yılında Çin'in ilk başarılı nükleer testinin gerçekleşmesinden sonra nükleer güce sahip olmanın ülkesel bütünlük ve bağımsızlı̆̆1 için elzem olduğu kanaati doğrultusunda nükleer çalışmalarını hızlandırmıştı. Hindistan'ın, Çin gibi nükleer bir güce sahip olan bir kötü komşusunun olması, tarafların aralarında sınır problemlerinin olması hatta bunun bir defasında yıkıcı bir savaş ile sonuçlanması; Hindistan'ı nükleer silahlanmaya yönlendiren en önemli etmenlerden biridir (İşbilen, 2009, s.74). Hindistan, aynı zamanda iç ve dış politikada 1962 yılında Çin mağlubiyeti ile kırılan milli gururunu nükleer silah elde ederek tekrardan güçlendirmek ve Çin'e gözdağı vermek istemekteydi. 


\section{Hindistan'ın Nükleer Güç Elde Etme Kaynakları?}

Hindistan'ın Güney Asya bölgesindeki nükleer önceliği nükleer fizikçi Homi J. Bhabha'nın nükleer enerjinin ülkenin kalkınmasını tetikleyecek bir etken olduğuna inanması ve bunu Hindistan'ın ilk başbakanı olan Nehru ile paylaşması ile süreç başlamıştır (Cohen and Diasgupta, 2010, s.97). Hindistan Atom Enerji Komisyonu ülkenin bağımsızlık ilanının hemen ardından Nehru'nun desteğiyle "Tata Temel Araştırmalar Enstitüsü" 1945 yılında kurulmuştur. Kurumun ilk başkanı olan Bhabha ile Hindistan, ilk sivil nükleer enerji çalışmalarına başlamıştır (Cohen, 2001, s.158). 1946 yılında ise, "Bhabha Atom Araştırma Merkezi" kurularak atom enerjisinden yararlanmak için çalışmalar yapılmaya başlanmıştır. 1948 yılında nükleer araştırmaların gelişimi için kurulan Atom Enerji Komisyonu 1954 yılında Atom Enerji Bakanlığına dönüştürülmüştür (Charnshy, 2014).

Bhabha ve Nehru, nükleer silah sahibi olan bütün devletlerin bu silahlara sahip olmadan önce ifade ettikleri gibi; nükleer enerjinin barışçıl amaçlar için kullanılmasına odaklanmışlardır. Bununla birlikte, Hindistan'daki tüm siyasetçiler ve fizikçi bilim adamları bu fikri desteklemişlerdir. Hindistan nükleer enerjiyi elde ettiğinde bu enerji hem ucuz maliyet ile büyük miktarda enerji sağlayacak hem de ülkenin kalkınma hızını artıracaktı. Nehru'nun uluslararası diplomasideki saygınlığ1 ve Bhabha'nın dünya çapında iletişim halinde olduğu önemli fizikçilerin desteği ile Hindistan'ın nükleer enerji elde etmesine yardımcı olmuştur (Mohan, 1998).

Hindistan ilk nükleer çalışmalarına Kanada ve Amerika'dan iki nükleer güç reaktörü elde ederek başlamıştır. 1965 yılında Hindistan'ın nükleer gücü sekiz kilogram plotonyum üretme kapasitesine ulaşmıştır ki bu en azından etkili bir nükleer silah yapmak için yeterli olmaktadır. Hindistan'ın reaktör teknolojisi, ağır su ve zenginleştirilmiş uranyumu yabancı kaynağa bağımlı olmasına rağmen; teknolojinin tasarım ve yapımına ilişkin bazı bölgelerde bağımsız davranabiliyorlardır (Cohen and Diasgupta, 2010, s.97). ABD'nin Hindistan'ın nükleer program geliştirmesine olan desteğini Soğuk Savaş konjonktüründe değer- 
lendirdiğimizde ABD'nin temel amacı Hindistan'ı olası bir Sovyet ittifakından uzak tutmaktır. Sovyetler ise, Hindistan'1 Komünist Blok'a yakınlaştırmak için cömert askeri yardımlarda bulundu.

ABD, Güney Asya nükleer pazarında etkin olmak amacı ile 1950-1960 arası Hindistan'ın nükleer güç elde etmesinde en önemli aktör olmuştur. Hindistan ise, $\mathrm{ABD}$ 'den tedarik ettiği nükleer alt yapı üzerinde $\mathrm{ABD}^{\prime}$ nin tasarrufundan hariç şekilde iyileştirmeler gerçekleştirdiğinden dolayı ABD yaptırımlarına maruz kalarak nükleer çalışmalarda Sovyetlere daha fazla yakınlaşacaktır (Mustafin, 2007, s.35-36). ABD, Güney Asya'da Hindistan'ı Çin yayılmacılığına karşı ilk önce bir nükleer güç olarak oluşturmak istememiştir. Buna rağmen Hindistan'ın bağımsız nükleer politikalarından da rahatsızlık duyarak verdiği desteği geri çekmiştir.

Nehru, güçlü bir orduya sahip olmanın yanında kolonizasyon döneminden kalan İngiliz militarist etkisini ortadan kaldırıp modern bir ordu kurmak istiyordu. Hindistan'ın yapmış olduğu nükleer araştırmalar muhtemelen bu kaygının bir sonucuydu. Hindistan 1974'te Pokhran'da ilk nükleer denemesini gerçekleştirmesiyle dünya kamuoyunun tepkisini çekmiştir (Akçağ, 2014). Hindistan'ın nükleer patlamayı başarılı bir şekilde gerçekleştirmesi ile birlikte Pakistan ile arasındaki silahlanmayı sadece konvansiyonel nicelik üstünlügünün yanında nitelik bakımından da değiştirmiştir (Bali, 2006, s.107).

Hindistan uzun ylllar nükleer gücü tekelinde tutan ülkelerin sahip oldukları nükleer gücü meşru olmayan bir ayrıcalık olarak algıladı ve NPT'yi imzalamamıştı. Hindistan, 1974 yılına kadar gizli olarak yürüttüğü nükleer faaliyetleri bu tarihten sonra açığa vurarak barışçıl amaç için kullanacağını ifade etmesine rağmen hiçbir ülke bu iddiaya inanmadı (Quinlan, 2009, s.133). Pakistan'ın 1998 yılında yapmış olduğu nükleer silah denemesi sonrasında bazı Hindistanlı bakanlar tarafından Hindistan'ın geliştirmiş olduğu nükleer silahların Pakistan' dan kaynaklanan tehditlerden dolayı olmadığını, Çin'den gelebilecek herhangi bir tehlikeye karşı hazırlıklı olmak için yapıldığı ifade edildi (Quinlan, 2009, s.137). Bununla birlikte, uluslararası ilişkilerin değişen konjönktüre göre şekillenmesi ile birlikte Hindistan-ABD ilişkilerinde yumuşama olmuştur. Soğuk Savaş döneminde SSCB'den nükleer teknoloji yardımı alan Hindistan, Soğuk Savaş sonrası dönemde Rusya'nın yardımlarıyla yüksek performansa sahip bazı balistik füzelerin, belirlenen hedefleri savaş 
gemilerinden atılarak vurmasına ilişkin başarılı çalışmalar gerçekleştirmiştir (Quinlan, 2009, s.139).

\section{Hindistan’ın Nükleer Güç Sahip Olmasının Bölgesel ve Uluslararası Politikaya Etkileri}

Uluslararası toplumda Hindistan'ın başarılı nükleer denemesine tepki oldukça farklı farklıydı. Bağlantısız Hareketi üye devletleri Hindistan'ın bu teşebbüsünü desteklediler. Fransa, Hindistan Atom Enerjisi Kurumuna tebrik mesajları gönderdi. ABD ise, Hindistan'ın nükleer enerjiye erişim araçları olan malzeme ve teknolojilerine kısıtlamalar getirilerek ambargo koymuştur. Hindistan nükleer programının gelişimine plütonyum ve reaktör desteği sağlayan Kanada ise, derhal Hindistan nükleer gücüne verdiği desteği kesmiştir (Charnshy, 2014). Hindistan'1n nükleer silah elde etmesi ile uluslararası sistemdeki prestiji şüphesiz artmıştır. Bir nükleer güç sahibi olan Hindistan, büyük güçler ile olan ilişkilerinde farklı bir katogoride değerlendirilmeye tabi tutulmuştur. ABD, Hindistan'ın ilk nükleer silah denemesine karşın bazı yaptırımlar uygulamak ile birlikte Soğuk Savaş şartlarını da dikkate alarak Hindistan'ı kendisinden uzaklaştırmamak için Hindistan'ı zora sokacak ve ilişkileri olumsuz etkileyecek tepkilerden de uzak durmuştur.

Hindistan iç politikasına bakıldığında, Soğuk Savaş sonunda Hindistan'da üç farklı yerli düşünce ekolü nükleer silahlanma üzerinde etkili olmuştur. Birinci gurup olan neoliberal ekol, ülkenin ekonomik gelişmesini temel hedef almışlardır. 1990 yılların başlarında Hindistan siyasetinde etkili olan gurup, ülkenin ekonomik iyileşmesini tehlikeye sokacak bir iddialı dış ve güvenlik politikasına ihtiyatlı bakmaktadırlar. İkinci gurup olan Nehrucular ise, nükleer silah yanlısıdırlar. Bunlar Nehru gibi Hindistan'ın ülkesel bütünlüğünün ancak nükleer silah sahibi olarak temin edilebileceğini düşünmektedir. Üçüncü gurup ise, güçlü savunmacılardır ki nükleer silahın sadece test edilmesi değil, ABD, Rusya ve Çin gibi modern nükleer cephanelikler oluşturulması ve hava, kara ve deniz üzerinden taşınabilen teknolojinin geliştirilmesini öngörmektedirler (Cohen and Diasgupta, 2010, s.101-102). Bürokraside, Hindistan'ın başarılı nükleer patlaması Başbakanlık koltuğunda oturan İndira Gandhi'nin de Hindistan siyasetindeki etkinliğini arttırmıştır. Gandhi, 1979 
y1lındaki seçimlerde galip gelmesinin bir nedeni de nükleer silah sahibi olan bir ülkeyi var etmesiydi.

Hindistan hükümeti nükleer güç elde etmenin ekonomik maliyeti konusunda detaylı bir ArGe çalışması yapmamıştır. Hindistanlı diplomatlar uluslararası toplumdan gelebilecek tepkiyi de ölçmekte yetersiz kalmıştır. Ayn zamanda nükleer silahlara sahip olma konusunda elle tutulur bir politika olmamasından dolayı Hindistan bu süreçte ağır ambargolara maruz kalmıştır (Mustafin, 2007, s.51). Hindistanlı yetkililer nükleer silah denemesinde barışçıl söylemler kullanmış olsa da bu real politikada karşılığı bulunmamaktadır. Aynı zamanda nükleer ekipmanların diğer ülkelerden tedarik edilmesi esnasında Hindistan ciddi oranda ekonomik kayba uğramıştır.

1988 yılında Hindistan-Çin ilişkileri karşılıklı ziyaretlerde bulunularak düzeltilmeye çalışılmıştır. Özellikle, 1990 yılında Çin ve Hindistan sınır anlaşmazlıklarını çözmek için önemli çalışmalar yapmışlarda neticede her iki ülkede sınırda hazır bekleyen askeri birliklerinin azaltılması kararını almışlardır (Arnet, 1998, s.11). Eski iki düşman ve rakip olan ülkenin ilişkilerinin bu şekilde bir yola girmesinin her iki ülkenin sahip olduğu büyük nüfus yapısı ve şüphesiz ki nükleer silahlardır.

Arı'nın (2000, s.170) ifade ettiği gibi; “Hindistan'ın 11 ve 13 Mayıs, Pakistan'ın ise 28 ve 30 Mayıs 1998'de gerçekleştirmiş olduğu nükleer denemeler nükleer silahların yayılması konusunda bölge ve dünya ülkelerini kaygılandırmıştır. Özellikle bu gelişme 1968'de imzalanan ve 1970'de yürürlüğe giren NPT pratikteki değerinin tartışılmasına ve Güney Asya'daki Hindistan ve Pakistan'ın bu tavrının uluslararası platformda yeniden ele alınmasına yol açmıştır. NPT'nin 9. Maddesinin 3. Paragrafında nükleer silahlara sahip olan devletlerin kimler olduğu belirtilmiştir. Buna göre, 1 Ocak 1967'den önce bu imkanlara sahip olan devletler; ABD, SSBC, İngiltere, Fransa ve ÇHC olduğu ifade edilmiştir. Dolayisıyla bu tarihten sonra hiçbir devlet Hindistan ve Pakistan gibi silahlara sahip olsa bile nükleer silahlara sahip olan devletler kategorisinde değerlendirilmemekte, tam aksine bu anlaşmaya aykırı hareket eden devletler olarak dikkate alınmaktadır." 


\section{Pakistan'in Nükleer Silahlanma Stratejileri}

Çalışmanın bu kısmında Pakistan'ın nükleer silah elde etme nedenleri detaylı bir şekilde analiz edilecektir. Bununla birlikte, İslamabad yönetiminin nükleer silahları elde etmede ne gibi araçlara başvurduğu ve ne gibi politik engellerle karşılaştığı tartışılacaktır. Ayrıca, Pakistan'ın nükleer silah elde etmesinin bölgesel ve uluslararası politikaya olan etkileri bu bölümde ele alınacaktır.

\section{Pakistan'ın Nükleer Silah Sahibi Olma Nedenleri}

İslamabad hükümetinin jeostratejik pozisyonu ve Delhi gibi güçlü bir komşusu ile yaşanan sorunların iki ülkeninde iç siyasetine bazı etkileri olmuştur. Özellikle orduların bu iki ülkenin özellikle Pakistan iç siyasetinde artan etkisi ülkenin sürekli bir askeri mücadeleyi sürdürmesi ile alakalıdır. Bugün Pakistan konvansiyonel anlamda dünyanın yedinci en kalabalık ordusuna sahip ve kitle imha silahı bağlamında da nükleer silahlara sahip olan bir ülkedir. Ordunun ülke siyasetindeki etkisi ve ağırlığ1 ülkenin sürekli bir şekilde askeri darbeler yaşamasına zemin hazırlamıştır. Pakistan'da bağımsızlık sonrası süreçte birkaç kez demokrasiye geçiş denemesi yapılmıştır. Fakat seçimlerin ardından gelen askeri darbeler seçimlerle iktidara gelen siyasetçileri işlevsizleştirmiştir (Çevik, 2013, s.16-17).

1971 yılında Pakistan'ın Hindistan ile yaptığı savaşta mağlup olması, Pakistan'ın nükleer güç elde etme isteğini tırmandırmıştır. Hindistan ve Pakistan 1971 yılından önce iki defa konvansiyonel ölçekte savaşmış ve bu savaşların her ikisinden de Pakistan yenik çıkmıştır. Bununla birlikte, 1971 savaşı ile Pakistan, Doğu Pakistan olarak adlandırılan Bangladeş'i de kaybederek toprak bütünlüğünü koruyamayarak parçalanmıştır. Pakistan'ın 1971 yılında Hindistan karşısındaki ezici mağlubiyeti ve bir daha bu şekilde kitlesel bir mağlubiyet yaşamaktan kaçınması Pakistan'ın nükleer silah programının oluşmasını doğurmuştur (Narang, 2009, s.47). Yahya Han'ın halefi olan Butto'da Hindistan'ın Pakistan'a karşı konvansiyonel üstünlügünün ancak nükleer güce sahip olmak ile dengelenebileceğinin farkındaydı (Dixit, 2002, s.333). Keşmir Savaşlarında Pakistan'ın Hindistan'a karşı devamlı yenilerek prestij kaybetmesi ve 1974 
yılında Hindistan'ın başarılı ilk nükleer silah denemesi Pakistan'ın güvenlik endişesini artırmıştır (Collins, 1997). Pakistanlı bir mühendis olan Abdulkadir Han, 1975 yılında Avrupa'dan ülkesine dönerek Pakistan'ın nükleer silah geliştirmesinde önemli katkısı olmuştur (Izuyama and Ogawa, 2003, s.64).

Bir nükleer güç olarak Pakistan, iç politikada Hindistan'dan daha fazla bütünlüğe sahiptir. Hindistan'a rakip olarak kazanmış olduğu veya kazanacağı askeri başarılar ve nükleer silah elde etmesi ise toplum için bir ortak payda niteliğindedir (Karaağaçlı, 2014). Çevik' in Hazırlamış olduğu "Pakistan Siyasetini Anlama Klavuzu"( 2013, ss. 115-116) adlı raporda da belirttiği gibi; "Pakistan'ın gerek ulusal kimliği gerek güvenlik stratejileri hep Hindistan üzerinden ve Hindistan karşıtlığına dayalı olarak belirlenmektedir. 1947' de yaşanan bölünmenin Hindistan tarafından hiç bir zaman kabul edilmediğine inanan Pakistan yönetimleri, Hindistan'ı her zaman ülkenin varlığını tehdit eden ana unsur olarak görmüşler ve Pakistan'ın varlığının da sürekli bir tehdit altında olduğunu varsaymışlardır. Ülkenin kuruluşunda göçmenlerin yüklendiği kritik misyon, bu güvensizliği ve kaygıyı daha da arttırmıştır. 1971'de Pakistan'ın ikiye ayrılmış olması da sonraki yıllara yönelik bu kaygıyı derinleştiren tarihsel bir olaydır. Tüm bu güvenlik kaygıları, ordunun Pakistan sistemi içinde oynadığı ağırlıklı rolün gerekçelerinden biridir. Ancak bu güvenlik kaygılarını hem derinleştiren hem de şekillendiren Pakistan'ın Hindistan karşısındaki yapısal zayıflığıdır. Hindistan ile konvansiyonel yollardan başa çıkmanın mümkün olmadığı tespiti, Pakistan ordusunu Hindistan ile mücadelede başka yollar aramaya sevk etmiştir. Bu açıdan Pakistan ordusunun konvansiyonel olmayan iki temel aracı kullandığı söylenebilir. Bunlardan birisi Pakistan'ın nükleer programıdır. Bu program 70'li yıllarda Hindistan'ın da nükleer silahlar edinme çalışmalarına başlamasının bir sonucu olarak Pakistan tarafından gereklilik olarak görülmüş ve en nihayetinde 1998 yılında Pakistan dünyanın yedinci resmi nükleer gücü olarak tescil edilmiştir."

\section{Pakistan'ın Nükleer Güç Elde Etme Yöntemleri}

Pakistan nükleer silah yapmak için teknik materyaller, cihaz haritaları ve sofistike parçaları Fransa, İngiltere, Amerika, Hollanda, Almanya, İtalya 
ve İskandinavya ülkelerinden dolaylı yollardan tedarik etmeyi başarmıştır. Çin ise, Pakistan'ın nükleer teknolojisinin gelişiminin temel destekçisidir. Çin, Pakistan'ın güvenlik açısından yetersiz nükleer tesislerine, özel teknolojik fırınlar ve ileri teknoloji teşhis ekipmanı satmıştır. Çin Nükleer Enerji Sanayi Kurumu ise bu ekipmanların kaynağının olduğu yerdir. Aynı zamanda Çin, Pakistan'a nükleer bomba üretimi için halka mıknatıslar ve çizimler tedarik etmekteydi. Çin'in yüksek dayanıklı fırınlarını Pakistan'a vermesi nükleer bomba için gerekli trityum'un imalatını kolaylaştırmıştır. ABD ise, zirkonyum ve kripton elektronik gibi nükleer bombayı tetikleyen cihazlar sağlamıştır. Almanya ve bazı İskandinav ülkeleri ise, elektronik bileşenler, trityum saflaştırma ve üretim tesislerinin kaynağını tedarik etmiştir (Dixit, 2002, s.333-334). Çin, Soğuk Savaş yıllarında Hindistan'ın olası tehlikelerini engellemek için Pakistan ordusunu modernize etmeye çalışmıştır. Bundan dolayı Çin, Pakistan'a önemli derecede balistik füze göndermiştir (İşyar, 2009, s.208).

1977 yılında Ziya'nın darbe yaparak Butto'yu idam etmesi PakistanABD ilişkilerine oldukça zarar vermiştir. ABD, Pakistan'ın Hindistan'a karşı nükleer bir denge oluşturma amacını iyi bilmekteydi ve bu nedenle Fransa ve diğer ülkelere İslamabad'a nükleer malzeme satmama konusunda baskı yaptı. Bununla birlikte, ABD-Pakistan ilişkileri tam uçurumun kenarına gelmişti ki, Afganistan'da yaşanan gelişmeler ikili ilişkilerin yumuşamasına neden oldu (Riedel, 2014, s.93). Bu süreçte Pakistan, ABD üzerinden bir takım stratejik kazanımlar elde etti. ABD, 1979 yılındaki Sovyetlerin Afganistan'ı işgal etmesine karşı Taliban'ı ABD ile varılan anlaşma sonucunda Pakistan üzerinden desteklemeyi tercih etti. Pakistan, ABD'ye destek vererek İslamabad'ın nükleer faaliyetlerini kısıtlamaya yönelik politikaların değişimini sağlamıştır.

1986 yılında Pakistan'ın Çin ile nükleer teknoloji transferine ilişkin önemli bir anlaşma imzalamıştır. Ziya'ül Hak ise "bu teknolojiyi (nükleer) elde etmek Pakistan'ın hakkıdır. Biz nükleer teknolojiyi elde ettiğimizde İslam Dünyası da nükleer silaha sahip olacaktır" diye ifade etmiştir (Mishra, 2014). Sovyetler 'in Afganistan'dan askerlerini çekmesiyle Pakistan-ABD ilişkilerinde de bazı anlaşmazlıklar ortaya çıkmıştı. ABD Senatosunda Pressler adı verilen bir yasa tasarısı ile ABD, Pakistan'a askeri 
malzeme temin etmeyi kesmişti. Bu anlamda, ABD, Pakistan'ın kendisinden satın almış olduğu F-16'ları teslim etmemekle birlikte para iadesi de yapmamıştı (Riedel, 2014, s.54).

Pakistan'ın nükleer silah elde ederek Hindistan karşısında nükleer denge oluşturarak güvenliliğini garanti altına almıştır. Pakistan, 1998 yılında ilk nükleer denemesini $1300 \mathrm{~km}$. menzilli Gauri adlı balistik füze denemesini yaptı. Sonraki yıl ise, $750 \mathrm{~km}$. menzilli $500 \mathrm{~kg}$ konvansiyonel ve nükleer başlık taşıyabilen Şahin 1 füzeleri ile nükleer gücünü ispatlamış oldu (Çelik, 2014).

\section{Pakistan'ın Nükleer Güç Elde Etmesinin Bölgesel ve Uluslararası Poli- tikaya Etkileri}

Soğuk Savaşın sona ermesi ile birlikte süper güçlerin doğal olarak sağladığı kısıtlamadan yoksun olan Güney Asya bölgesi dünyanın diğer bölgeleri gibi bir takım çatışmalara sahne olmuştur. 1998 yılında Hindistan ve Pakistan'ın yeraltında nükleer denemeler yaptığında bölgedeki güvensizlik hat safhaya ulaşmıştı. Uluslararası toplum, diplomatik anlamda her iki ülkeye tepki gösterse de Hindistan ve Pakistan, nükleer kulübe dâhil olmak için bu tepkilere çok aldırış etmedi (Hook, 2014, s.228).

1998 Mayısında Hindistan'ın ardından Pakistan'ın art arda nükleer denemeler yapması ile ABD tarafından her iki ülkeye ekonomik ambargo yapılmıştır. Ancak bundan Hindistan'dan ziyade Pakistan ekonomisi daha fazla sorun yaşamıştır. Ayrıca Pakistan-ABD ilişkileri Soğuk Savaş koşullarının ortadan kalkması ile Pakistan'ın sahip olduğu stratejik öznelliğini kaybetti. Bununla birlikte, Pakistan'ın Afganistan'da ki Taliban gücünü desteklemesi ve 1998 Pakistan'ın kanunlarında yaptığ 1 radikal değişimler Pakistan-ABD ilişkilerini olumsuz yönde etkilerken ABD, Hindistan ile ilişkilerini geliştirme kararı almıştır. Pakistan, nükleer teknoloji elde etmede Çin'e bağımlı olduğundan dolayı ABD-Pakistan ilişkilerini bozan bir etken de bu olsa gerek( (Arı, 2000, s.182; Swami, 2007, s.144). ABD ve Pakistan arasında yaşanan gerginlikler Pakistan'ın Çin'e olan askeri bağımlılığı artmış olup, ABD'nin Hindistan'a yakınlaşmasına da neden olmuştur.

10 Mayıs 1998 yılında Hindistan'ın gerçekleştirdiği nükleer silah denemesine Pakistan tarafından nükleer bir karşıllık verildi. Bu denemeler 
üzerinde her iki ülkeye Birleşmiş Milletler tarafından ciddi ambargo uygulanmasına rağmen, Pakistan'ın terörizme karşı bir Batı müttefiki olduğundan, Hindistan'ın ise dünyada gelişen ekonomisi ve artan politik öneminden dolayı ambargolar hafifletildi ve zamanla kaldırıldı (Quinlan, 2009, s.134-135). Bununla birlikte, Pakistan nükleer silah sahibi olduktan sonra bazı ülkelere nükleer silah teknolojisinin transferine aracılık etmiştir. Irak başta olmak üzere (Prinçci, 2010, s.369) Libya, Kuzey Kore ve İran'a Pakistan aracılığı ile ciddi miktarda nükleer teknolojinin altyapısı ulaştırıldığı düşünülmektedir.

Pakistan' in nükleer silah elde etmesi ile birlikte Hindistan, Pakistan'ın nükleer gücünü zayıflatmak ve kontrol altında tutmak için Pakistan ile kapalı kapılar arkasında diplomatik diyaloglar geliştirmeye çalışmıştır. Hindistan, Pakistan ile çıkacak olası bir savaş durumunda nükleer silahların kullanılmasını engellemeye yönelik bazı adımlar atmak istemiştir. Pakistan ise, Hindistan'ın ezici konvansiyonel gücünü bildiği için Hindistan'ın teklifini samimi bulmamıştır (Lodi, 2014). 1999 yılında Pakistan sahip olduğu nükleer gücün şımarıklığ ile Hindistan kontrolündeki Keşmir bölgesinde yer alan Kargil'e askeri birliklerini yerleştirerek bu bölgeyi işgal etmeye çalışmıştır. Hindistan ise, temkinli davranarak bölgedeki çatışmaların nükleer bir savaşa dönüşmemesine dikkat etmiştir (Panday, 2014). (Swami, 2007, s.144)

11 Eylül 2001 terörist saldırılarından hemen sonra, Bush yönetimi, Clinton yönetiminin Pakistan'ın nükleer faaliyetlerinin açığa çıkmasından sonra koyduğu bütün yaptırımları kaldırmıştır. ABD'nin bu tutumu Pakistan'ın nükleer çalışmalarını kabullenmesinden ziyade, Taliban ve ElKaidenin koruması altına olan Afganistan'a karşı iş birliği yapılması ortak hareket edilmesinden kaynaklanmaktadır (Izuyama and Ogawa, 2003, s.81). Bununla birlikte, 2005 yılında ABD-Hindistan arasinda imzalanan Sivil Alanda Nükleer İşbirliği Antlaşması Pakistan'ın güvenliği için bir yıkım niteliğindeydi. ABD uzun yıllar Hindistan'ın balistik füze savunma sistemleri teknoloji talebine sıcak bakmazken, aynı ABD, Patriot Advanced Capability 3 ismindeki ileri düzey balistik füze savunma sistemini Hindistan'a satmak ve ortak olarak daha da geliştirmek istemiştir (Özkan, 2014).

Pakistan ve Hindistan'ın nükleer silah elde etmeleri ile birlikte ekonomik ve siyasi nedenlerden dolayı dışa bağımlılıkları azalmanın 
aksine paradoksal bir şekilde artmıştır. Pakistan, olağan askeri operasyonlarında ABD F-16 uçaklarını kullanırken nükleer saldırılar için Fransız yapımı Mirage-III ve V olan çok amaçlı uçakları görevlendirmektedir. Hindistan ise, Fransız Mirage 2000, Anglo-Fransız nükleer silah taşıyabilen Jaguar veya yeni tip Rus Su-30 uçaklarını aktif olarak kullanmaktadırlar. Bundan dolayıdır ki Pakistan, ABD askeri ambargosuna maruz kaldıktan sonra Çin ve Fransa'ya olan bağımlılığı artmıştır (Arnet, 1998, s.2).

Pakistan son olarak Mart 2015'de nükleer başlık taşıyan balistik füze denemesini başarıyla gerçekleştirmiştir. Pakistanlı yetkililer ise yapılan çalışmaların devam edilerek füzelerin 1720 milden daha fazla uzaktaki hedeflere karşı gelişiminin sağlanacağını belirtmiştir. Yapılan bu çalışmalar Pakistan'ın Hindistan'a yönelik caydırıcılığını güçlendirirken Hindistan'ın tepkisine yol açmıştı (Hussain, 2015).

\section{Hindistan ve Pakistan'in Nükleer Doktrinleri}

Çalışmamızın bu bölümünde Hindistan ve Pakistan'ın benimsemiş oldukları nükleer doktrinlere açıklık getirilmeye çalışılacaktır. Özellikle Hindistan'ın benimsediği no first use (ilk kullanan olmama) ve Pakistan'ın benimsediği first use (ilk kullanan olma) üzerinde iki ülkenin nükleer doktrinlerinin oluşum nedenleri ele alınacaktır.

\section{Hindistan'ın Nükleer Doktrinleri}

İlk kullanan olmama (No First Use), Hindistan'ın herhangi bir çatışma veya büyük ölçekli bir savaşta nükleer silahı ilk kullanan olmama politikası, sadece nükleer dış politikasını açıklayıcı bir ilke ve stratejik araç olarak görülmelidir. Bu nedenle güvenlik politikası bağlamında bağlayıcı bir meşruiyeti olması söz konusu olamaz. Pakistan ise, Hindistan'ın bu politikasını sadece kâğıt üzerinde varlığını kabul etmektedir. Ayrıca Hindistan'ın bu doktrini tek taraflı olduğundan istenildiği zaman rahatlıkla yürürlükten kaldırılabileceği düşünülmektedir (Kazi, 2014).

Her ne kadar 1998 yılından sonra Hindistan ve Pakistan'a küresel ölçekte ekonomik ve diplomatik yaptırımlar uygulansa da iki ülke nükleer politikalarından taviz vermemekte ısrarlı davranmışlardı. Hindistan, 
Ağustos 1999 'da yerde, havada ve denizde konuşlu nükleer füzeleri ile "asgari güvenilir caydırıcılık" doktrinini ilan etmiştir. Bu doktrinine ek olarak ise, 2000 yılında savunma harcamalarında \%28 artışı onaylamıştı (Hook, 2014, s.231).

2003 yılı Hindistan'ın Nükleer Doktrini; Hindistan Güvenlik Kabine Komitesi, Hindistan'ın nükleer doktrini şu maddeler halinde beyan etmiştir:

1. Güvenilir ve inşa edilebilir asgari caydırıcılık sağlamak. Bunun anlamı Hindistan'ı tehdit edebilecek herhangi bir gücü caydıracak nükleer kapasiteye sahip olmayı ifade eder.

2. İlk kullanan olmama (no first use) doktrini; nükleer silahların kullanımı sadece Hindistan toprakları veya askeri güçlerine karşı uygulanan nükleer saldırılara karşı misilleme amacıyla kullanılacaktır.

3. Nükleer misillemede ilk vuruş büyük ve kaldırılamaz zarar vermek için olacaktır.

4. Nükleer saldırı karşısında misillemeye yetkili sadece Nükleer Komuta Kurumu'nun sivil siyasi lideridir.

5. Nükleer silahlar, nükleer silah olmayan ülkelere karşı kullanılamaz.

6. Hindistan, topraklarına karşı biyolojik ve kimyasal kitle imha silahları ile saldırıldığında nükleer gücünü kullanabilir.

7. Nükleer güç ve füzelere ilişkin madde ve teknolojilerin ihracatında sıkı kontroller yapılmasının sağlanmasına devam edilmektedir (Chandra, 2014).

Genel olarak ele alındığında Hindistan'ın tanımladığı nükleer doktrin, nükleer silahlarının sadece nükleer güç sahibi olan düşman bir devletten (Çin veya Pakistan) gelebilecek nükleer saldırı veya tacizlere misilleme olarak bu silahları kullanacağı anlamına gelmektedir. 2014 yılına gelindiğinde Hindistan 2003 yılındaki nükleer doktrinini değiştirmeye yönelik çalışmalar yapmıştır. Elbette bu değişime yönelik nedenler güçlü ve yerindedir. Bunlar; küresel politikada Rusya-ABD arasında yapılan ordu ve silahları sınırlandırma antlaşmaları, savaş meydanındaki düşmanın askeri yeteneklerindeki değişim (Pakistan'ın $60 \mathrm{~km}$ menzili olan Hatf-IX elde etmesi), nükleer ve kitle imha silahlarından kaynaklanan yeni tehditler ve mevcut şartlar altındaki nükleer doktrinin başarısızlığıydı (Balachandran and Patil, 2014). 


\section{Pakistan'ın Nükleer Doktrinleri}

Pakistan'ın nükleer doktrini şekillendiren 1947 yılından itibaren Hindistan ile arasında çıkan savaşlarda üç kez mağlup olması, 1971 yılında Doğu Pakistan'ın Hindistan'ın gayretleri sonucu Pakistan'dan ayrılması etkili olmuştur. Özellikle çözüme kavuşturulamayan Keşmir meselesinden dolayı her iki ülkenin Keşmir sınırlarında ordularını hazır bekletmesi Pakistan'ı güvenlik politikalarını oluşturmada daha çok dikkatli davranmaya yöneltmiştir (Lodi, 2014). Hindistan'ın açık bir nükleer doktrini olmasına rağmen Pakistan'ın böyle bir doktrini söz konusu değildir. Fakat Pakistan'ın izlemiş olduğu dış politika ve nükleer faaliyetlerden ülkenin nükleer doktrinin ne olduğu konusunda bazı çıkarımlarda bulunabilmemiz mümkündür. Pakistan, Hindistan'ın ezici askeri gücünü kabul ettiği ve konvansiyonel olarak dayanabilecek potansiyeli olmadığından dolayı temel nükleer doktrini ilk kullanan olma (first use) stratejisidir.

Pakistan'ın nükleer silahlanma konusunda ki diğer bir doktrini Hindistan'ın sahip olduğu konvansiyonel gücün caydırıcılı̆̆ 1 özeline dayanmaktadır (Krepon, 2014). Bunun yanında Pakistan, Hindistan'dan algıladığı konvansiyonel bir saldırı veya düşmanı olan ülkelerden stratejik olarak hassas bir darbe yemesi ile nükleer gücünü kullanabileceği anlaşılmaktadır (Nayyar, 2008, s.4). Her ülkede olduğu gibi Pakistan'ın da sahip olduğu nükleer silah ile sahip olduğu konvansiyonel askeri gücü arasında inkâr edilemez bir bağ vardır. Birbiri arasında potansiyel çatışma ihtimali yüksek olan iki nükleer askeri güce sahip ülkeden konvansiyonel olarak zayıf olan tarafın güçlü olan tarafın kendisine yönelik bir saldırı karşısında ilk kullanan olması oldukça tabidir. Pakistan da kendi güvenlik ve toprak bütünlüğünü bu nükleer politika ile sağlaması şuanda da geçerlidir (Kanwal, 2014). Hindistan ise, Pakistan'ın böyle bir nükleer saldırısı karşısında Pakistan'ı topyekûn yenilgiye uğratacak hatta tarih sahnesinden silebilecek karşı nükleer saldırıya geçmesi de reel politik beklenti olmaktadır.

Her iki ülkenin nükleer doktrini karşılaştırıldığında; Hindistan'ın Güney Asya'yı aşan daha geniş ölçekli stratejik nükleer politikaları varken, Pakistan nükleer doktrinini Hindistan'a karşı saldırı bağlamında belirlemiştir. Hindistan herhangi bir konvansiyonel çatışma veya saldırıda ilk nükleer silah kullanan taraf olmamak isterken; Pakistan ise, 
konvansiyonel bir saldırıya uğradığında ilk kullanan taraf olacağı doktrinine sahiptir. Hindistan nükleer saldırılarda karşı tarafa asgari caydırıcılık vermek isterken, Pakistan'ın buna yönelik bir politikası bulunmamaktadır. Hindistan'ın nükleer silahları sivil irade tarafından kontrol edilirken, Pakistan'ın nükleer silahları de facto olarak yönetimde bulunan askeri liderler tarafından kontrol edilmektedir (Badrulalam, 2014).

Pakistan'ın konvansiyonel bir saldırı karşısında sahip olduğu nükleer silahları Delhi'ye karşı tereddütsüz kullanacağını ifade etmesi ve Hindistan'ın ise böyle bir mukabele karşısında Pakistan'a bir yıkım yaşatacağ 1 korkusu bölgenin istikrarı için büyük kaygı taşımaktadır. 2004 yılında yapılan bir araştırmaya göre Güney Asya kıta parçasında karşılıklı bir nükleer savaş olma durumunda en az 100 milyon insanın sadece patlama anında öleceği ve yüz binlerce insanın ise dolaylı olarak bu savaştan zehirlenip öleceği veya sakat kalacağı anlaşılmaktadır (Crompton, 2007, s.94).

\section{Sonuç}

II. Dünya Savaşı'nın son günlerine gelindiğinde ABD'nin 6 Ağustos 1945 tarihinde Japonya' nın Hiroşima kentine "little boy" isimli atom bombasını atması ile dünya nükleer silahların tahrip gücü ile tanışmıştır. Bununla beraber, bu silahların caydırıcılığından (deterrent) kaynaklanan gücün etkisi ile bir ülkenin nükleer silah sahibi olması durumunda diğer devletler nazarında ve uluslararası politikada ne kadar güçlü bir statü elde edeceği de anlaşıldı. ABD'den sonra Sovyetler, İngiltere, Fransa ve Çin'in nükleer silah sahibi olması ile birlikte, uluslararası politikada nükleer ayrıcalık ve dokunulmazlık daha önemli ve dikkat çekici bir düzeye gelmiştir. Özellikle, nükleer güçlerden herhangi biri ile kötü komşuluk ilişkisine sahip olan devletler kendi güvenliklerini ve çıkarlarını sağlamak adına nükleer güç sahibi olmak istemiştir.

Hindistan ve Pakistan 1947 yılında bağımsızlıklarını elde etmekle birlikte, her iki devlet günümüze kadar devam eden ve hala çözülmeyen bir takım problemlere de sahip olmuşlardır. Keşmir sorunu, İndus Havzasının statüsü, her iki ülkede bulunan azınlıkların vatandaşı oldukları devlet ile olan problemleri başta olmak üzere iki devlet arasında birçok ayrışma konusu bulunmaktadır. Keşmir Sorunu hâlihazırda, Filis- 
tin Sorununa benzer bir şekilde II. Dünya Savaşı sonrası inşa edilen sistemin en kalıcı problemlerinden birisi olmaya devam etmektedir. Dini, etnik ve bölgesel anlamda Hindistan ve Pakistan arasında Keşmir'in kontrolü adına amansız bir rekabet devam etmektedir. Yüzbinlerce insanın hayatını kaybetmesine, milyarlarca doların silahlanmaya ayrılmasına ve ülkelerin iç politikalarında önemli siyasi sorunlara neden olan Hindistan-Pakistan uyuşmazlığının çözümsüzlüğü devam etmektedir.

Hindistan ve Pakistan'ın arasındaki güvensizlik ve edinilen yıkıcı tecrübeler tarafların Güney Asya coğrafyasında birbirlerine karşı mutlak güç elde etmek için gerek konvansiyonel gerekse nükleer anlamda silahlanmalarına neden olmuştur. Çalışmada ulaşıldığı üzere, Hindistan'ın Çin'den kaynaklı tehdit algısı Hindistan'ı nükleer silahlanmaya yönlendirirken Pakistan, Hindistan gibi nükleer ve konvansiyonel olarak güçlü bir devlet karşısında varlığını devam ettirmesini yalnızca nükleer güce sahip olarak mümkün görmektedir.

Hindistan ve Pakistan, nükleer güç elde etmek ve ulusal güvenliğini kitle imha silahları aracılığı ile korumak için ekonomik, siyasi, askeri ve hukuki anlama önemli bedeller ödemiştir. Bununla beraber, teknolojik ve nükleer güç anlamında etkin olan devletlerin kendi pragmatik politikaları çerçevesinde masa altından nükleer silah teknolojilerini Hindistan ve Pakistan'a sattığı veya teknik yardımların ulaşmasına göz yumduğu anlaşılmaktadır. Her iki ülke arasındaki kronik sorunların bulunması ve bunun dönem dönem düşük veya yüksek yoğunluklu askeri çatışmalara dönüşmesi Güney Asya bölgesel güvensizliğe oldukça zarar vermektedir.

Hindistan ve Pakistan'ın nükleer faaliyet ve politikalarını incelediğimiz bu çalışmada; her ülkenin çok özel nükleer silah elde etme sebepleri bulunmaktadır. İki ülkenin de sahip oldukları temel nükleer doktrinlerin de ayrı olması ve hangi koşullarda bunları kullanacakları belli olmaması bölgedeki istikrarsızlık ve silahlanmayı ileride de devam ettirecekleri izlenimi vermektedir. Diğer bir taraftan, uluslararası toplumun nükleer silahların yayılmasını engellemek için normatif çözümler bulamaması ilerleyen yıllarda da nükleer silahlanmanın hem Güney Asya bölgesinde hem de dünyanın diğer bölgelerinde artmasına neden olabilir. Bu da devletlerarasındaki ihtilafları çözmede nükleer silahlara sahip olma veya kullanma eğiliminin daha fazla yaygınlaşmasını tetikleyebilir. 
EXTENDED ABSTRACT

\title{
India and Pakistan Relations: The Effects of Regional Competition on Nuclear Armament Strategies
}

*

\author{
Engin Koç \\ Bursa Teknik University
}

This study analyzes the nuclear activity and policies of two neighboring, competitor, and enemy countries, India and Pakistan. The issue of armament, especially nuclear armament, constitutes a particular field of international relations studies. The USA used its nuclear weapons for the first time against Japan in the last days of World War II and wanted to keep it as a deterrent force against the Soviets. The Soviets, on the other hand, acquired nuclear weapons in a short period and tried to redress the balance against the USA by supporting the establishment of nuclear weapons technology in China. India was supported to counterbalance China, and ultimately Pakistan was supported to counterbalance India.

After India gains its independence, an unexpected division took park among the societies living in this region. As a result, two new states, India and Pakistan, were found in August 1947. The inability to manage Kashmir and other disputes have led to a battle between India and Pakistan multiple times, and the ceasefire between the two countries to be broken many times. After the parties increased the armament and defense expenses over the Kashmir issue, this occasion has led to an increase in the current security dilemma.

One other important issue addressed in this study is the Nuclear Armament Strategies of India and Pakistan. Even though India had problematic relations with Pakistan since 1947, these relations could be managed. On the other hand, China's occupation of a part of Indian territory in 1962 and after that, Beijing's possession of nuclear weapons in a short period led to vital changes in the Indian defense strategy. Again, Pakistan's problems with India growing gradually and losing the 1971 battle led Pakistan to seek nuclear weapons. However, the separation of Bangladesh, formerly East Pakistan, from Pakistan has been a substantial tragic event for 
Pakistani politicians, and efforts to obtain nuclear weapons have been an essential factor in rebuilding the national pride of Pakistan.

If we examine the sources of obtaining nuclear weapons technology in India, both the USA and the USSR provided generous technological assistance to this country with the effect of the Cold War conjuncture in the 1960s. In consequence of the adverse events between the USA and India, the Delhi government turned its face to Moscow. On the other hand, Pakistan has managed to provide technical materials, device maps, and sophisticated parts indirectly from France, England, America, Netherlands, Germany, Italy, and Scandinavia countries to acquire nuclear weapons. In particular, China provided considerable assistance to Islamabad in constructing new nuclear facilities and the performance of technology transfer.

India and Pakistan being nuclear powers have had significant effects on both regional and international politics. As France congratulated India's achievements regarding the nuclear weapons work, the USA and Canada decided to impose sanctions on Delhi. In domestic politics, political groupings support the efforts to develop nuclear weapons, prioritizing the economy, and that is entirely opposed to nuclear weapons, have emerged. Even though India has stated that it will peacefully use this technology for its security and energy requirements, this claim has not been compelling. After Pakistan's first successful nuclear explosion, several countries imposed sanctions on Islamabad. As the poor bilateral relations with the USA brought Pakistan-China relations to a strategic level, India's discomfort towards China and Pakistan gradually increased.

When the nuclear doctrines of India and Pakistan, which are nuclear power, are considered, it is seen that there are significant differences. No First Use, India's policy of not being the first to use nuclear weapons in any conflict or large-scale battle should be seen only as a principle and strategic tool to explain its nuclear foreign policy. Thus, it cannot have a binding legitimacy in the scope of security policy. Pakistan, on the other hand, considers that this policy of India is only on paper. Nevertheless, as this doctrine of India is unilateral, a consideration regarding that it can be quickly repealed at any time exists. Pakistan was defeated three times in the battle with India since 1947, and that shaped its nuclear doctrine, and East Pakistan's separation from Pakistan in 1971 due to India's efforts 
were influential. When examined, even though India has a clear nuclear doctrine, Pakistan does not have such a doctrine. Still, it is possible to make some inferences about the country's nuclear doctrine by looking at Pakistan's foreign policy and nuclear activities. Since it accepts India's overwhelming military power and has no potential to withstand conventionally, Pakistan is a first-use strategy of fundamental nuclear military doctrine.

Comparing the nuclear doctrine of both countries, India has largerscale strategic nuclear policies that transcend South Asia, while Pakistan has set its nuclear doctrine in the scope of a direct attack against India. While India desires not to be the first to use nuclear weapons in any conventional conflict or attack, Pakistan has the doctrine that it will be the first to use nuclear weapons in a conventional attack. While India wants to provide the least deterrence to the opposite side in nuclear attacks, Pakistan does not have a policy. When seen from another perspective, India's nuclear weapons are controlled by the civilian will, while the ruling military leaders de facto control Pakistan's nuclear weapons. Considering eventually, we can conclude that the distrust and the destructive experiences between India and Pakistan caused the armament of the parties in both conventional and nuclear terms in order to gain absolute power against each other in the South Asian geography.

\section{Kaynakça / References}

Akçağ, E. (2014). Yükselen güç Hindistan, (28.09.2018) tarihinde http://www.bilgesam.org/incele/84/-yukselen-guc-hindis$\tan / \# . V C g q S W d \_$uYs adresinden erişildi.

Arı, T. (2000). Global politika ve güney asya: Keşmir sorunu ve nükleer yarış, 2 b., Bursa: AlfaYayınları

Ar1, T. (2004). Irak, Iran ve ABD, Bursa: Alfa Yayınları

Arı, T. (2008). Uluslararası ilişkiler ve dış politika, 7b., Bursa: MKM Yayıncılık

Arnett, E. (1998). Nuclear weapons and arms control in South Asia after the test ban, New York: Oxford University Press

Badrulalam, M. (2019), India and Pakistan's nuclear doctrines: A coparative analysis, (01.10.2019) tarihinde http://www.sspconline.org/opinion/India Pakistans NuclearDoctrines 11042012 adresinden erişildi. 
Balachandran G. and Patil, K. (2014). Revisiting India's nuclear doctrine, (05.11.2018) tarihinde http://idsa.in/idsacomments/RevisitingIndiasNuclearDoctrine gbalachandran 200614.html adresinden erişildi.

Balbay, M. (2006). İran raporu, İstanbul : Cumhuriyet Kitapları

Bali, E. (2006), Hindistan ve Pakistan'ın dış politika tercihlerinin Soğuk Savaş ve Soğuk Savaş sonrası yansımaları, Ankara Üniversitesi Sosyal Bilimler Enstitüsü Uluslararası Illişkiler Ana Bilim Dalı (Basılmamış Yüksek Lisans Tezi), Ankara

Bektaş, M.H.M. ve Gündoğdu, A.Y. (2019), IŞiD'in hibrit savaş stratejileri: Hibrit savaş konsepti perspektifinden analizi, International Journal of Politics and Security, IJPS, 2019, 1(1): 25-56.

Birdişli, F. (2011). Ulusal güvenlik kavramının tarihsel ve düşünsel temelleri, Erciyes Üniversitesi Sosyal Bilimler Enstitüsü Dergisi, 31(2), 149-169.

Chandra, S. (2019), Revisiting India's nuclear doctrine: Is it necessary? (29.10.2019) $\quad$ http://idsa.in/issuebrief/RevisitingIndiasNuclearDoctrine schandra 300414.html adresinden erişildi.

Charnysh, V. (2019). India's Nuclear Program, (02.11.2019) tarihinde http://charnysh.net/Documents/charnysh_india_analysis.pdf adresinden erişildi.

Climbala, S. J. (2010). Nuclear weapons and cooperative security in the 21st century, New York: Routledge Global Security Studies

Climbala, S. J. (2010). Nuclear weapons and cooperative security in the 21st century, Routledge Global Security Studies

Cohen S. P. (2001). India: EmergingPower, Washington, D.C.: Brookings Institution Press

Cohen S. P. and Dasgupta. S. (2010). India's Military modernization, Washington D.C.: Brooking Institution Press

Collıns, A. (1997). The Security Dilemma and the end of the Cold War . Edinburgh: Keele University

Crompton, S. W. (2007). Pakistan, 2th New York: Chelsea House Publishers

Çevik, S. (2013). Pakistan siyasetini anlama klavuzu, Seta Rapor

Dixit, J. N. (2002). India and Pakistan in War and peace, New York: Routledge

Erkin, E. (2011). Çin 'in Orta Asya politikaları, Ankara: Hoca Ahmet Yesevi Uluslararası Türk- Kazak Üniversitesi Yayınları, No:4

Hook, S. W. ve Spainer, J. (2014). Amerikan Dış Politikası: İkinci Dünya Savaşından Günümüze, İstanbul: İnkılap Kitabevi 
Hussain, T. (2019). Pakistan Tests Nuclear Capable Missle in Burgeoning Asia Weapons Race, (15.04.2019) tarihiden http://www.mcclatchydc.com/2015/03/09/259107/pakistan-tests-nuclear-capable.html adresinden erişildi.

Izuyama M. and Ogawa, S. (2003) The nuclear policy of India and Pakistan, NIDS Security Reports, No.4

İşbilen, E. (2009). Nükleer satranç: İran'ın Nükleer politikası, İstanbul: Ozan Yayıncilik

İşyar, Ö. G. (2009). Karşılaştırmalı dış politikalar, Bursa: Dora Yayınları

Kadercan, B. (2014). Güç, ed. Şaban Kardaş ve Ali Balcı, Uluslararası ilişkilere giriş, 3b., İstanbul: Küre Yayınları

Kanwal, G. (2020). Pakistan's Nuclear threshold and India's Options, (10.03.2020 ) tarihindehttp://observerindia.com/cms/export/orfonline/modules/analysis/attachments/A355 1199862929995.pdf p.4. adresinden erişildi.

Karaağaçlı, A. (2014). Pakistan'da uluslaşma ve kimlik sorunu, (26.09.2014) tarihinde $\quad$ http://www.bilgesam.org/incele/82/-pakistan\%E2\%80\%99da-uluslasma-ve-kimlik-sorunu/\#.VCgqPWd_uYs adresinden erişildi.

Kazi, R. (2014). Why India Should Retain Its No First Use Policy, (05.11.2014) tarihinde http://idsa.in/idsacomments/WhyIndiashouldretainitsNoFirstUsepolicy rkazi 110411.html adresinden erişildi.

Kibaroğlu, M. (2006). Kitle imha silahları ile terör: Kıyametin eşiği mi?, Avrasya Dosyast, 12(3), 119-137

Kissinger, H. (2005). Çin, Çev. Nalan Işık Çeper, İstanbul: Kaknüs Yayınları

Krepon, M. (2014). Pakistan's Nuclear Strategy and Deterrence Stability, (22.11.2014) tarihinde http://www.stimson.org/images/uploads/research-pdfs/Krepon - Pakistan Nuclear Strategy and Deterrence_Stability.pdf p.7. adresinden erişildi.

Lodi, S. (2014). Pakistan's Nuclear Doctrine, (10.10.2014) tarihinde http://www.defencejournal.com/apr99/pak-nuclear-doctrine.htm adresinden erişildi.

MisHRA, R. K. (2014). Nuclear and Missile Threats to India: China-Pakistan Nexus in South Asia, (10.10.2014 tarihinde http://www.southasiaanalysis.org/paper296) adresinden erişildi. 
Miş, N. (2016). Keşmir: Bağımsızlık mücadelesinde bitmeyen savaş, Dünya Çatışmaları, Çatışma Bölgeleri ve Konuları, Ed. Kemal İnat, Burhanettin Duran ve Muhittin Ataman, Ankara: Nobel Yayınları

Mohan, R. (2014). India and Nuclear Powers, (02.11.2014) tarihinde http://library.fes.de/pdf-files/ipg/ipg-1998-4/artmohan.pdf s.337. adresinden erişildi.

Mustafin, R. (2007). Hindistan'ın Nükleer Politikası, Ankara Üniversitesi Sosyal Bilimler Enstitüsü Uluslararası İlişkiler Ana Bilim Dalı (Basılmamış Yüksek Lisans Tezi), Ankara

Narang, V. (2009). Posturing for Peace? Pakistan's Nuclear Postures and South Asian Stability. International Security, 34(3), 38-78.

Nayyar, A. H. (2008). A Pakistani perspektive on nuclear disarmament and non proliferation, FES BriefingPaper, No: 9

Özey, R. (2007). Küresel silahlanma Dünya'nın silah depoları, İstanbul: Aktif Yayincilik

Özkan, G. (2014). Pakistan- ABD ilişkilerini düzeltmek neden (25.09.2014) zor?,http://www.usakanalist.com/detail.php?id=138 adresinden erişildi.

Panday, A. (2014). The Stability-Instability paradox: the case of the kargil war, (09.11.2014) tarihinde, http://psujia.files.wordpress.com/2012/04/thestability-instability-paradox-the-case-of-the-kargil-war.pdf p.7. adresinden erişildi.

Pirinçci, F.(2010). Silahlanma ve savaş, Bursa. Dora Yayıncıllk

Polk W. (2007). Irak'ı anlamak, Çev.Nurettin Elhüseyni, İstanbul: NTV Yayınları, 2.b.

Quinlan, M. (2009). Thinking about Nuclear Weapons: Principles, problems, prospects, New York: Oxford University Press

Riedel, B. (2014). Kıyametin eşiğinde Amerika, Hindistan ve Pakistan sarmal, Çev.Arzu Birkan, İstanbul: Matbuat Yayınları

Sagan, S. D. (1996).Why do states build nuclear weapons?: Theree Models in Search of a Bomb. International Security, 21(3), 54-86.

Sönmezoğlu, F. Güneş, H. ve Keleşoğlu, E. (2015). Uluslararası ilişkilere giriş, 6b., İstanbul: Der Yayınları

Swami, P. (2007). India, Pakistan and The Secret Jihad The Covert War in Kashmir:1947-2004, Asian Security Studies Routledge 
Temizel, S. (2019). Kağıt Kaplan- Zayıf bir pakt Olarak Güneydoğu Asya Antlaşması Teşkilatı (SEATO) ve bölgesel siyasi etkileri, Sosyal Bilimler Araştırmaları Dergisi, Ekonomi-Politik Özel Sayısı, 285-302.

Waltz, K. (1981). The spread of nuclearweapons: More may better, Adelphi Papers, Number 171，1981，(01.11.2020) tarihinde http://polsci.colorado.edu/sites/default/files/10B Waltz.pdf adresinden erişildi.

Wohlstetter, A. (1958) The delicate balance of terror, Rand (10.12.2020) tarihinde https://www.rand.org/pubs/papers/P1472.html. adresinden erişildi.

Yılmaz M. E. (2013). Savaş ve uluslararası sistem, Bursa: Dora Yayınları,2b.

\section{Kaynakça Bilgisi / Citation Information}

Koç, E. (2021). Hindistan ve Pakistan ilişkileri: Bölgesel rekabetin nükleer silahlanma stratejilerine etkileri. OPUS-Uluslararası Toplum Araştırmaları Dergisi, 18(40), 2744-2774. DOI: 10.26466/opus. 857115. 